\section{Maurício Tragtenberg *}

1. 0 "Modo Asiático de Produção". 2. A Evolução da Emprêsa Industrial sob o Capitalismo e a Teoria Geral da Administração como Ideologia. 3. Terceira Fase da Industrialização. 4. Conclusão.

\title{
A Teoria Geral da Administração é uma Ideologia?
}

A administração, enquanto organização formal burocrática, realiza-se plenamente no Estado, antecedendo de séculos ao seu surgimento na área da emprêsa privada.

O segrêdo da gênese e da estrutura da teoria geral da administração, enquanto modêlo explicativo dos quadros da emprêsa capitalista, deve ser procurado onde "certamente seu desenvolvimento mais pujante se dá: no âmbito do Estado". 1

Enquanto o capitalismo industrial, estruturando a emprêsa burocrática, encontrou, nos vários modelos da teoria geral da administração de Taylor aos estruturalistas ou sistêmicos, um modêlo explicativo, no século $X X$, a transição das sociedades pré-industriais a industriais gerou um modêlo recorrente do "modo de produção asiático", neste século unido à máquina. Dal, a emergência da burocracia como poder funcional e político, ${ }^{2}$ elemento típico das civilizações orientais, ${ }^{3} \mathrm{em}$ plena era cibernética. Foi Hegel que, no plano lógico, operacionalizou o conceito "burocracia" em nível do Estado e da emprêsa.
Hegel é um dos primeiros estudiosos da burocracia, enquanto poder administrativo e político, formulando o conceito: "onde o Estado aparece como organização acabada", 4 considerado em si e por $\mathrm{si}^{5}$ "que se realiza pela união íntima do universal e do individual"."

\footnotetext{
* Professor de política da Escola de Sociologia e Política de São Paulo.

1 Touraine, Alain. Historia general del trabajo. México, Ed. Grijalbo, 1965. vol. 4.

2 Marx, Karl. El capital. Madrid, Ed. Aguillar, 1930. v. único e Weber, Max. Economía y sociedad. México, Ed. Fondo de Cultura Económica, 1944. v. 4, cap. 7, p. $176-78$ o "modo asíatico de produçáo" fôra enunciado inicialmente por John Stuart Mill em 1848 e Montesquieu no seu L'esprít des lois, posteriormente desenvolvido sistematicamente por Marx, Karl. In: El capital. v. único, cap. 11, p. 244 Weber, Max, Economia y sociedad. v. 4, cap. 7, p. 176-78; Godelier. El modo de producción asiático. Argentina, Ed. Universitaria de Cordoba: Witfogel, Karl.

Wirtschaft un Gesselchaft China's. v. 1 desenvolvendo sistematicamente o tema em Oriental despotism, a comparative study of total power. Yale, 1951.

3 "Esse modo de produção aplica-se em geral a paises com grandes extensóes deserticas, onde as condiçoes climaticas obrigavam, a um atendimento particular, organização da irrigaçáo artificial pelos canais; essa area estende-se pelo Saara aos plateaux mais elevados: OEgito india e Tartária". Baizacou, Hélène Antoniadis. e Tartaria". Baizacou, Helene Anton asiatique. La pensée. p. 49.

- Hegel Principes de la philosophie du droit. Paris, Ed. Galimard, 1940.

6 Hegel. op. cit. p. 190.

- Hegel. op. cit. p. 191.
} 
Para Hegel, o Estado como "realidade moral", como "síntese do substancial e do pa:ticular, ${ }^{7}$ contém o interêsse universal enquanto tal, que é sua substância, ${ }^{8}$ deduzindo-se então, ser o Estado, a "instância suprema que suprime tôdas as particularidades no seio de sua unidade". 9

Sendo o Estado para Hegel a "realidade em ato" da liberdade concreta ${ }^{10}$ que se "conhece", pensa e realiza pelo fato de sê-lo, ${ }^{11}$ sua finalidade é a integração dos interêsses particulares e individuais. Essa integração não suprime a antinomia (interêsse geral) e a sociedade (conjunto de interêsses corporativos e particulares). Essa antinomia manifestase na existência de interêsses particulares das coletividades que pertencem à sociedade civil e que estão fora do "universal em si mesmo e por si do Estado" e são administrados pelas "corporações nas comunas e em outros sindicatos e classes por suas autoridades: presidentes, administradores. Esses negócios, que êles cuidam, representam a propriedade $e$ o interêsse dessas esferas particulares", 12 o que não impede a transitividade do espírito corporativo da burocracia empresarial privada, à pública do Estado, na medida em que ela "nasce da legitimidade das esferas particulares e transforma-se internamente, ao mesmo tempo, em espírito do Estado, pois encontra nêle 0 . meio para atingir seus fins particulares". 13

Hegel procura sintetizar na corporação (entendida como burocracia privada) e no Estado (entendido como burocracia pública acabada), as múltiplas determinações que levam à tensão entre o interêsse particular e o universal do Estado; na existência da burocracia que pressupõe as corporações, ela, enquanto burocracia estatal, é o formalismo de um conteúdo situado fora dela: a corporação privada. ${ }^{14}$

O objetivo do Estado torna-se o objetivo da burocracia, cujo espírito é o segrêdo mantido no plano interno pela rigidez hierárquica no fluxo de comunicação, e pelo seu caráter de corporação fechada, no plano externo. Encontramos assim em Hegel as determinações conceituais que permitem a análise da burocracia do Estado, da burocracia enquanto poder político que antecede em séculos a emergência da burocracia determinada pelas condições técnicas da emprêsa capitalista, oriunda da Revolução Industrial.

A burocracia, enquanto classe dominante (detentora dos meios de produção) elemento de mediação com a sociedade global, exercendo o poder politico, perfila-se ante a história como uma forma de dominação burocrático-patrimonial ou

"modo asiático de produção". No modo asiático de produção, o déspota oriental representa a confluência de um processo social que se inicia com a burocracia surgindo das necessidades técnicas (irrigação da terra arável) finalizando como poder de exploração, efetuandose assim a transitividade da burocracia cumprindo funçōes de organização e supervisão para o monopólio do poder político. ${ }^{15}$

0 modo de produção asiático surge na sociedade quando aparece o excedente econômico, que determina uma divisão maior de trabalho separando mais rigidamente agricultura $\mathrm{e}$ artesanato, que reforçam a economia consuntiva, 16 à qual sobrepõe-se o poder representado pelo chefe supremo ou uma assembléia de chefes de família. Dá-se a apropriação do excedente econômico por uma minoria de indivíduos sem retribuição à sociedade. Daí a exploração assume a forma de dominação, não de um indivíduo sôbre outro, mas de um indivíduo que personifica uma função sôbre a comunidade. ${ }^{17} \mathrm{~A}$ necessidade da cooperação simples, onde a máquina tem papel secundário e a divisão de trabalho é incipiente para a realização de obras que sobrepassam as comunidades, vai requerer uma direção centralizada para coordenar os seus esforços. $\mathrm{Na}$ medida em que isso se dá, unido à eficiência do trabalho, é possível a transformação do sentido funcional da autoridade superior em instrumento de exploração das comunidades subordinadas, quando se dá a apropriação da terra pelo Estado, que mantém a propriedade comunal. 0 indivíduo continua na posse da terra como membro de sua comunidade particular.

Assim, a cultura de irrigação junto com a horticultura e a irrigação pelos grandes rios criam a necessidade de uma supervisão centralizada que irá recrutar mão-de-obra relativamente ampla.

\footnotetext{
7 Hegel. op. cit. p. 196.

- Hegel. op. cit. p. 200.

- Hegel. op. cit. p. 218.

10 Hegel. op. cit. p. 195.

11 Hegel. op. cit. p. 190.

18 Hegel. op. cit. p. 220.

18 Hegel. op. cit. p. 226.
}

1 Para Hegel, na medida em que se

estrutura a carrejra burocrática no Estado, este passa a constituir finalidade

privada do funcionário; para prevenir essa disfunçăo, Hegel apela à "formação moral dos funcionários públicos".

2s "Os efeitos da cooperação simples no modo asiático de produção, aparecem em seu aspecto colossal nas gigantescas obras dos antigos asiáticos, egípcios e
etruscos. $\mathrm{Na}$ antiguidade, tais estados asiáticos, depois de empregarem a maioria de seus recursos na area civil e militar, possuiam um excedente de produtos utilidade. O domínio que, sóbre máo-de-obra de tal populaçåo năo ocupada na de tal população năo ocupada na disfor de tal excedente, possuíam o rei e os sacerdotes, o erecia-lines os meios para levantar aqueles ingentes monumentos que cobria o pais. Utilizou-se quase construção e transporte daquelas estátuas colossais e daquelas enormes massas cuja possibilidade de terem sido transportadas ainda hoje nos assombra. Para de trabalhadores e unificar seu esforço." Marx, Karl. El capital. Madrid, Ed.

Aguiliar, 1931. v. único, cap. 1, p. 244. 10 Para Max Weber, economia consuntiva é sinónimo de economia natural; no entanto "não se conhece ainda nos séculos XIV e XV, for exemplo, entre os Médici, a separação sistemática do regime de economia consuntiva (natural e economia lucrativa)." Weber, Marx. Historia econo. mica general. México, Ed. Fondo de Cultura Económica, i956. p. 8.

17 Conforme pesquisa do jurista-historiador Maitland, F. W. The survival of archaic comunities, In: Collected papers. Cambridge, 1911. 2 v.. e ainda Weber, Marx. Der Srat un den Charakter der

altgermanischen Sozial-verfassung. In Jahrbf. Nationalokonomie un Statistik, Max ${ }^{83}$ 1904, idêntico processo, acentua
Weber, deu-se na formação da lugoslavia $a$ Crościa contrariando a tese de via e Croacia contrariando a tese

Zeistschrf, Sozial un Wirtschafteeschichte. v. 7. 1900, que vê nessa estrutura o resultado da organizaçáo tributária de
Bizâncio. 
A sorte dos judeus no Egito está ligada a êsse processo; são recrutados à fôrça para as expedições dos reis assírios e babilônicos que, com seus séquitos, procuram reunir

mão-de-obra para construção de canais e cultivo das zonas desérticas. Nesse sentido, a via fluvial do Nilo desempenhou papel vital na centralização burocrática, 18 atuando como fator decisivo na formação de uma hierarquia de clientes subordinada diretamente ao Estado patrimonial-burocrático. ${ }^{19}$

0 contrôle da água em grande escala é dirigido pelo Estado e seu caráter centralizado e despótico no Egito repetia-se na antiga Mesopotâmia ${ }^{20} \mathrm{e}$ China onde os cultivadores passivos e ignaros estão "sob direção de uma classe letrada de funcionários que planejam e executavam o plano. Incapaz de organizar-se, o camponês chinês sofre a dominação tirânica do Estado. ${ }^{21}$ Daí a supremacia tirânica da burocracia estatal chinesa", 22 reforçada pela ausência ainda maior dos senhorios territoriais, que apesar dela ainda existiam no Egito, tendo sido substituídos pela burocracia construtora de canais, de depósitos para armazenamento de tributos in natura, de onde os funcionários retiravam suas congruas ou emolumentos, abastecendo - Exército. No início da época histórica da China, dar-se-á a regularização das águas, atribuída às qualidades carismáticas de um soberano demiurgo, 0 grande YU. ${ }^{23}$

O modo de produção asiático não é confinado ao Egito antigo. A Mesopotâmia, China ou o Império incaico conheciam-no. Êle aparece na Rússia por ocasião da invasão huna, determinando a longo prazo "certos aspectos da vida social e econômica que a nós ocidentais podem parecer impostos pela Revolução Autoritária (1917), mas que são de fato prolongamentos de instituições preexistentes, desenvolvimentos decorrentes de pensamento da antiga Rússia", 24 fornecendo a chave para a compreensão da realidade russa contemporânea.

$\mathrm{Na}$ Rússia antiga, a comunidade de aldeia (ebchtchins), posse coletiva do solo, é uma criação do govêrno, imposta aos camponeses por razões administrativo-fiscais, onde, conforme o Ruskaya Pravda (o direito russo) o "proprietário eminente de tôda a terra é o Grão-Principe. Os boiardos constituem um exército móvel mantido pelo Príncipe que 'convida' sua gente" para recolher tributos em gêneros, mel, cêra, cereais, etc.; o mesmo se faz nas cidades organizadas comunalmente. Os "homens do Príncipe" aparecem como proprietários rurais com terras para sua subsistência e sobretudo domínios florestais. Em 1326, o Metropolita de Vladimir instala-se em Moscou colocando, assim tôda a influência de um clero a serviço do Grão-Príncipe, fornecendo, quadros, à burocracia estatal. 0 Grão-Príncipe distribuiu domínios aos camponeses (pomestye) a título precário, em recompensa pelos seus serviços, constituindo uma nova aristocracia ligada ao poder, os boiardos. Estes submetiam-se ao Grão-Príncipe e participavam do seu Conselho, a Duma. ${ }^{25}$

Este Estado onipotente, fundado nas prestações forçadas de serviço, exercendo um contrôle máximo sôbre a propriedade territorial, constitui-se num elemento básico para explicação da persistência do mesmo, através do tempo, conforme explica Summer.

Modernamente na URSS o modo asiático de produção predomina de forma recorrente, no seu aspecto mais significativo: o realce ao domínio da burocracia enquanto poder político, no regime do capitalismo do Estado. ${ }^{20}$ Ésse regime é uma combinação inédita ${ }^{27}$ de iniciativa individual no plano econômico com a economia do Estado. ${ }^{28}$

O capitalismo de Estado, ou melhor, o processo de modernização levado a efeito por uma elite, industrializante sob a direção de um partido único, implica nos seus inícios, já na burocracia. ${ }^{2 \theta}$ Essa burocratização já ameaça, três anos após a tomada do poder por Lênin, ${ }^{30}$ o regime na sua totalidade. 0 monopólio do poder, pelo partido único, é o elemento que assegura a seleção da elite

13 "Sem ela (a vla fluvial do Nilo) não teria a centralização burocrática alcançado, no Egito, o grau que efetivamente sociedad. v. 4, cap. 6, p. 602.

io No Egito antigo deu-se "a submissão da povoaço a prestaçסes pessoais numa proporçăo que antes nẳo fóra possível e conduziram o Antigo Império a uma situaçăo em que tóda povoação estava organizada numa hierarquia de clientes (dependentes), na qual o homem sempre fol considerado boa prêsa; em alguns casos foi incorporado as quadrilhas de escravos de Farat

20 A respeito, o magistral estudo de Rustow, Alexánder. Ortsbestimmuung der Gustow, Alexander. Zurich, Erienbach, 1950-52. 2 v. a Weber, Max. op. cit. vol. 4, cap. 7 p. 178.

I Maspero, H. \& Balazs, E. Histoire et institutions de fa Chinne ancienne

France, Ed. PUF, 1967, cap. 1, 4.a parte, p. 169-70, retomando uma tese idêntica p. 169-70, retomando uma tese identica despotism, Yale, 1951.

28 Conforme Maspero, H. \& Balazs, E. 28 Conforme Maspero, H. \& Balazs, E.
op. cit. p. 170 , idéntico processo dera-se na op. cit. p. 170, idéntico processo dera-se de tecnologia neolica, a burocracia "governava teocraticamente sôbre uma sociedade hidráulica simple p. 117 . Tal ponto de vista reforcado por um cronista incaico da répoca, Vega, Garcilaso de la. Comentarios época, Vega, Garcilaso de la. Comentarios reales de los Incas. 1945, v. 1, cap. 1, p. 282 observara "a falta de retriburçáo pelos serviços prestados no trabalho obrigat das estradas, construção de pontes, canais de
Estado".

Estado". Meyer, Monique. L'entreprise industrielle 2 Meyer, Monique. L'entreprise industrient
d'état en Union Sovietique. Paris, Ed. Cujas, 1964. p. 11.

${ }_{\infty}$ "A influência mongólica na transmissão à Rússia dos métodos despóticos do estatismo da China, aparece com clareza na Rússia de Moscou, eis que os mongóis conheciam êsses métodos nuando

submeteram a Rússia (1273-40), pois anteriormente haviam conquistado a Chin (1211-22) e Turquestâo em 1219-20. Desde 1215, Gengis Khan tinha um conselheiro chinés de alto nlvel, Yeh-lúCh'u-Ts'ai. Em 1253, o Grande Khan Mongke, no iniuito de um contróle racional da área sob seu dominio, ordenou a

Pieh-erh-ke que fizesse um censo na Rússia". American Philosophical Society. History of Chinese society. Philadelphia, 1949. v. 36.

2 Não há nenhum livro que fale do $\mathrm{Ca}$ pitalismo do Estado na época do comunismo. Marx mesmo nåo escreveu nada a respeito, morreu sem deixar nenhuma respeito, morreu sem deixar nenhuma vel." Lênin. La révolution bolcheviste. Paris, Ed. Payot, 279 .

Paris, Ed. Payot, P. 279. visto por nós, náo é analisado em nenhuma visto por nós, nao é, "Lúnin. op. cit. p. 279 .

p. 279 .

" "Um tipo misto, em que a iniciati

privada limitada pela estatização "Falamos do renascimento parcial da burocracia no interior do regime soviético." Lénin. o canitalismo de estado e o impósto em espécie. Curitiba, Guaira, s/d. p. 46.

o "Vemos apresentar-se esse mal diante de nós. ainda mais claramente, mais ameacador e mais nítido", (Lênin. op. cit. p. 47) concluindo que na Rússia "a burocracia nảo está no Exército, mas nos serviços". Lênin. op. cit. p. 47. 
dirigente, ${ }^{31}$ onde a ascenção na escala partidária assegura igual subida na burocracia do Estado. ${ }^{32}$ Esta burocracia possui - Estado como propriedade privada, dirigindo coletivamente os meios de produção, ${ }^{33}$ é a tecnoburocracia dirigente, que persiste de Lênin até hoje, ${ }^{34}$ mas, vigiada pelo partido, não possui nem os meios de produção como apropriação privada, nem a hereditariedade de fortuna.

Nesse contexto, o administrador de emprêsa cumpre a função de realizar no nível de microemprêsa os objetivos do plano. Se êle atinge as cifras do plano recebe bonificação, ${ }^{35}$ isso implica uma correlação entre o lucro planejado e o efetivamente conseguido.

Se o lucro planejado é conseguido, uma parte dêle fica retida no fundo da emprêsa, as bonificações constituem parte importante na remuneração dos dirigentes; ${ }^{36}$ no entanto, o método no pagamento das bonificações é o maior responsável pela malversação dos recursos.

A irracionalidade do sistema de bonificações leva os diretores de emprêsas a dissimular sua capacidade produtiva, a acumular inùtilmente equipamentos, matérias-primas, evitar inovações e produzir bens sem utilização. Um dos vícios do sistema é encorajar a direção da emprêsa a dissimular sua capacidade produtiva, na medida em que a superação dos objetivos quantitativos é a condição básica para atribuição de bonificação. ${ }^{37}$

Isso leva a competição entre os diretores no sentido de estocarem matérias-primas, e os que têm mais prestígio têm maior sucesso. A bonificação constitui-se em freio à inovação na medida em que essa provoca uma perturbação na produção, significando menor bonificação para o gerente e o operário. Se houver maior produção devido à inovação, os planejadores retificam as metas, tornando-as mais difíceis de atingir. A emprêsa é sempre incitada nesse sistema a produzir bens inúteis ou com pouca demanda, conduzindo a malversação no âmbito dos bens de consumo, pois a direção limitará a variedade dos artigos para atingir maior produção quantitativa. ${ }^{38}$

A emprêsa trabalha sob contrôle hipercentralizado, ${ }^{39} \mathrm{com}$ planos confirmados trimestralmente pelo Estado russo. A grande maioria das emprêsas dependia de comissários e ministérios setoriais.

Em 1957, a indústria é dirigida centralizadamente e setorialmente, gerando a proliferação de órgãos administrativos e os males da departamentalização, estudados por Selznick, onde se dá a bifurcação de interêsses entre as subunidades com objetivos próprios. A especificação de zonas geoeconômicas levava ao encarecimento do transporte e à falta de coordenação entre as emprêsas da indústria local. Na medida em que os setores industriais dependiam de um ministério específico, cada um procurava assegurar seu aprovisionamento, enquanto cada ministério ficava preocupado com seu setor, mais do que com os outros; isso coexistia com uma centralização direcional rígida no âmbito da emprêsa. ${ }^{40}$ Nessa estrutura, os comitês de emprêsa limitam-se a reforçar a decisão que Ihes foi transmitida pelos órgãos centrais. ${ }^{41}$

O fenômeno da centralização burocrática da direção da emprêsa, gerida no nível mais alto pelo partido que detém o monopólio do poder, não se dá sòmente na URSS, Hungria ou Tcheco-Eslováquia, é persistente na lugoslávia também.

E o ressurgimento do modo asiático de produção, aliado ao alto nível de tecnificação com o monopólio do poder pelo partido único.

Assim, a nova classe emerge como elite industrializante, como uma conseqüência do desenvolvimento gradual da elite clandestina que constituía a estrutura do partido nos anos de luta pelo poder. "Troque por nova classe o têrmo
31 "Pois ainda que haja poucas exceçóes, os quadros de direção não podem chegar geralmente ao nivel de diretor de

fábrica sem a condiçåo prévia de serem membros do P.C." Granick, David. EI hombre de empresa soviético. Mad
Revista do Ocidente, 1966. p. 40 .

39 "Assim em 1958 a delegaçăo norteamericana mencionava que o Diretor da maior usina siderúrgica de Chelyabinsk fóra antes Secretário do Partido naquela zona," Granick, D. op. cit. p. 44.

33 "Caracteriza-se essencialmente pela apropriação dos instrumentos de produção pelo Estado." Portal, R., Os eslavos.

Lisboa, 1968. p. 408 .

at "A tecnoburocracia industrial, administrativa militar e planejadora, embora

muito poderosa sob a ditadura de Stalin,

muito poderosa sob a ditadura de Stalin,

de seu mito obediente a

ao seu orgấo supremo: o P.C." Gurvitch, G.

ao seu orgao supremo: o P.C." Gurvitch,

Paris, Ed. PUF, 1966. p. 222.

35 "Essa proporcaão pode atingir a $30 \%$ ou $40 \%$ do salário pròpriamente dito. E necessário esclarecer que essa estrutura observa-se na indústria na URSS." Lewit.

Rev. Sociologie du Travail, (2): 127, 1970.

Onde o exemplo por excelência de remune-

ração é o salário por tarefa (p. 158)

que corre o risco de ser dividido por

atraso ou falta ao trabalho; neste caso

"recomenda-se destinar aos bons

trabalhadores a parte devida aos maus

como recompensa por sua fidelidade".

Lewit. cit. p. 167

so "A luta pela tabela diferencial de remuneração leva implícita a noção de que

- igualitarismo é estranho à sociedade

socialista. Os organismos sindica is devem

lutar sem cessar contra as tendências

igualitarias (Hungria)." Lewit. op. cit.

p. 175; daí na Tcheco-Eslováquia - segundo

o diário Obdoran, n. 21, 1968 - os

salários dos manobristas representam 10\%

dos do diretor adjunto (Lewit. op. cit.

p. 154).

37 Tal forma de remuneração arcaica fôra definida por Taylor no início do século onde "a tarefa e a gratificação constituem um dos mais importantes elementos do funcionamento da administracão cientifica". Taylor. Administraçáo cientiffica do trabalho. p 110 . No século passado por ocasiāo da Revolucão Industrial, analisando as condicóes inglessas, K. Marx acentuava: as trabalho por tarefa e um sistema arcaico que tem na Inglaterra um nome muito que tem na Inglaterra um nome mu suador)".' Marx, K. El capital. v. único. p. 410.

ss. "Há necessidade de elaborar em caráter experimental para futuro proximo formas de salário que correspondam as condiçöes de trabalno modernas, da mesma forma que o salário por unidade correspondeu que o salaridade da geraçăo anterior." Christian, Dejean, La salaire au rendemene, un exemple belge. Rev. Soc. du Travail, (2), 1961

æaspecialmente por ocasião da II Grande Guerra "o traco característico da organizaçắo é a centralização feroz de tôda direção econômica". Dudorine. Planification et programation lineaire de 'aprovisionnement matériel et téchnique. Ekonomizdat Moscou, 1961 p.

to "No ápice de tơda emprêsa, oficina e secão, acha-se um chefe investido de todo poder para direça, impondo uma disciplina de ferro durante o trabalho sujeito a vontade de um s6: do dirigente soviético." Meyer, M. op. cit. p. 90 "O diretor de emprésa é fundamento do Poder Socialista". Kaminster. Manual de I'entreprise industrielle. Moscou, 1961, sendo "nomeado e liberado de suas funçōe pelos 6rgãos superiores, cf. parágrafo 89 do Regulamento sôbre a Emprêsa

Produtiva Socialista do Estado." Meyer, M op. cit. p. 900 . O \& $94 \mathrm{da}$ Lei investe o contramestre de plenos podêres e organ zaçăo direta da produção e do trabalho, responsável pela execução do plano. Sua transferencia, nomeação ou licenciamento são efetuados pelo diretor da emprésa; essa "burocratização" da direção, fruto do centralismo, engendra a burocracia. Dudorine. Planification et programation lineaire de l'aprovisionnement matériel et téchnique. Ekonomizdat. Moscou, 1961. p. 18.

12 "A participaçăo é formalmente assegurada mas os trabalhos não têm nenhum 
aparelho e tudo ficará mais nítido." 42

A concentração do poder na figura carismática de Tito leva-o ao papel de "Grande Animador" do sistema, único possuidor de crítica; êle abre a campanha de crítica com observações e recomendações que caracterizam periòdicamente a vida da lugoslávia. Aí também os órgãos de autogestão representam a burocracia dominante. ${ }^{43}$

Isso nos permite definir as formações econômicas e de emprêsa na URSS e no âmbito da Europa Oriental, como formas de modo de produção asiático recorrentes ao capitalismo do Estado, onde a burocracia, não só é o elemento oriundo das necessidades funcionais da técnica, mas é acima de tudo poder político total.

Isso tem implicação no plano das idéias: êsse sistema cria automàticamente a valorização no primeiro plano do conhecimento político doutrinário e o conhecimento filosófico restrito ao marxismo interpretado pelos detentores do poder; sua dogmatização é acompanhada do monopólio do poder pelo partido único do qual emerge o Iíder carismático. Em segundo plano aparece o conhecimento científico e, em último, o conhecimento técnico, como elementos de refôrço do sistema.

Vimos que a emergência da burocracia patrimonial como poder político nas sociedades orientais e pré-colombiana antecede de muito o aparecimento da burocracia funcional da indústria moderna, confirmando o aforismo hegeliano que a substância do Estado é a realização do interêsse universal enquanto tal (da burocracia). Isso se dá na URSS, Europa Oriental e nos países de autocracia modernizante. O Estado aparece como um triunfo da "razão" hegeliana, onde a maturidade política é conquistada por mediação da burocracia, que introduz a unidade, na diversidade da sociedade civil. O Estado como "burocracia acabada" gera a sociedade civil, o regresso de Marx a Hegel.

\section{A EVOLUÇAO DA EMPRESA INDUSTRIAL SOB O CAPITALISMO E A TEORIA GERAL DA \\ ADMINISTRAÇAO COMO IDEOLOGIA}

A análise da teoria geral da administração como ideologia implica o estudo do "fenômeno do pensamento coletivo que se desenvolve conforme interêsses e as situações sociais existentes". ${ }^{44}$

As premissas gerais para a emergência do capitalismo fundamentam-se na contabilidade racional como norma para emprêsas que satisfazem as necessidades diárias. Elas se estruturam na propriedade privada dos meios de produção, técnica racional, direito racional, estrutura administrativa da burocracia e um ethos do trabalho e esfôrço contínuo. Em suma, o capitalismo foi o produto "da emprêsa, contabilidade e direito racional unidos à ideologia racional e ética racional na economia". ${ }^{45}$

A primeira Revolução Industrial encontra respostas ideológicas sob a forma de teorias sociais globais: Saint-Simon, Fourier e Marx. Eles elaboraram modelos macrossociais, tendo em vista as condições institucionais da sociedade industrial global; a segunda Revolução Industrial, que se inicia com a introdução da eletricidade, a formação dos grandes holdings industriais, encontra como resposta intelectual a teoria clássica da administração, nos estudos de Taylor e Fayol. Fundamentada sistemàticamente num período de acumulação de capitais, isso conseguido, surge à tona o problema humano na emprêsa industrial, e a elaboração da Teoria das Relações Humanas com Elton Mayo. ${ }^{46}$ Os dilemas da sociedade industrial, bem como as inconsistências dos postulados da Escola das Relações Humanas são retratados criticamente pela Escola Estruturalista que aparece na Alemanha, baseando-se em algumas indicações de Marx, sistematizadas por Max Weber. ${ }^{47}$

\subsection{A primeira Revolução Industrial}

A emergência da revolução industrial implica uma alteração das condições de produção,

poder efetivo. Houve centralismo exacerbado participacão simbolica." Meyer, M. op. cit. p. 22; idêntico fenómeno Lewit constatou estudando uma emprésa Lewit constatou estudando uma empresa
do que isso, que os assalariados do que isso, que os assalariados
rejeitam os fins propostos pela direca. rejeitam os fins propostos pela direçao. t2 Djilas, Milovan. La nouvelle classe dirigéante. p. 48-48; ponto de vista confirmado por pesquisas na lugoslávia por Albert Meister, que constata o país
dirigido por quadros com formação tecnodirigido por quadros com formação tecn A análise a respeito da concentração A análise a respeito da concentraçáo de Djilas - de que o poder é monopolizado pelos apparatchks (os profissionais da cúpula do partido), ativistas e gestionários da propriedade coletiva. Meister, A Socialisme et autogestion. Paris, Presses
Universitaires de France, 1953. p. 274-75.

43 "Os 6rgãos de autogestação não conquistam nada, êles recebem, são beneficiários, são-lhes atribuídas competências, liberdades e feudos. Sua criação não é o produto de reivindicaçåo popular, mas foi doada ao povo pelos seus

A Manheim Karl. Ideologia e utopia.

Ed. Globo, 1950. p. 115.

45 Weber, Max. Historia económica general. p. 298.

48 "E de lembrar-se que nas sociedades onde há escassez, ou seja, em que a maioria dos cidadáos está de braços com os problemas do subconsumo, os fatos problemas do subconsumo, os fatos materiais tendem a assumir excessiva socialmente o problema do consumo, graças a alta produtividade do sistema graças a alta produtividade do sistema da conduta humana estilizam-se. perdendo relevância o fator económico, ao mesmo tempo em que outros motivos, antes subsidiários, aumentam sua influência. o atraso moral é, em certo sentido, uma seqüela crónica do complexo de escassez. Inversamente, o elemento etico é inseparável da síndrome de abund

pertinentes, quando nos cingimos a estera da organizaçăo." Ramos, G., Administração e estratégia do desenvolvimento. Rio,

i7 Foi na Alemanha que se deu a reação à Escola das Relaçōes Humanas, vista como desenvolvendo uma atitude

manipulativa para com o operário em função dos interêsses da Administração. Neste aspecto, Elton Mayo continua Taylor e Fayol; a crítica alemã mostrara que a Escola de Relações Humanas subestimava o conflito, negara o pêso dos fatôres económicos determinantes da paz industrial; tinha a tendência a encarar as relaçōes industriais como relacoos interindividuais. A Alemanha foi 0 berço da reação intelectual a Escola das Relaçōes Humanas, pelo fato de que, industrializando-se tardiamente em relação a Inglaterra e França, a ela restará pensar no plano crítico o que a primeira realizou na Economia (Rev. Industrial) e a segunda no político (Rev. Francesa). Nos EUA, apesar do desenvolvimento econômico, năo se tomara tal postura crítica, porque "onde as classes já constituidas mas não fixas, ainda se modificam e substituem freqüentemente, ao contrário dos seus elementos constitutivos, onde os métodos de produção moderna, em lugar de corresponder a uma superpopulação constante, compensam muitas vézes a falta relativa de braços e cabecas, e onde por fim, o nỏvo e febril movimento de produçá material que tem um mundo novvo a conquistar, năo possui nem tempo nem ocasižo para destruir o velho mundo espiritual". Marx, Karl. Le 18 brumaire de Louis Napoleon.' Editions Sociales, 1928. p. 33. 
substituição da manufatura pela fábrica, absorção do êxodo rural na nova mão-de-obra industrial, transferência de capitais do campo à cidade $e$ aproveitamento dos resultados das ciências naturais no universo industrial.

O desenvolvimento da máquina a vapor dependia bàsicamente dos estudos dos gases de Boyle, das investigações sôbre a física do calor de Blach e Carnet e dos trabalhos sôbre a conservação da energia de Helmholtz. Sem as experiências de Faraday, a respeito das bases fisicas da eletricidade e do magnetismo, não teríamos o dínamo ou o motor elétrico; as pesquisas sôbre os gases e a eletricidade permitiram o surgimento do motor de combustão interna. A química é a precursora dos progressos da indústria do ferro, aço e petróleo. As investigações de Ampère permitiram o surgimento do telégrafo e o trabalho de Hertz deu a possibilidade a Marconi de inventar o telégrafo sem fio. A máquina a vapor e o motor de combustão interna superaram o boi e o cavalo, como fôrça motriz.

A Revolução Industrial iniciou-se na Inglaterra porque fôra o país mais afetado pela Revolução Comercial; 48 eis que o sistema industrial medieval fundado nas guildas desapareceu em primeiro lugar na Inglaterra, no século XI, no ramo têxtil, já fôra suplantada pelo trabalho doméstico, permitindo o incremento do processo de industrialização.

No século XVIII, a classe comercial inglêsa suplantara a holandesa, e com a acumulação de capital inglês possibilitou a criação de uma marinha mercante, que por sua vez reforçou a acumulação.

0 incremento da demanda de artigos têxteis, em 1700, demonstrara a escassez de artesãos; daí a necessidade dos meios mecânicos.

O "cercamento" das terras para criação de pastagens destinadas a manter o rebanho for- necedor de lã à manufatura têxtil urbana liberou mão-de-obra para a indústria.

No plano continental, a França foi o primeiro país que sofreu as conseqüências das transformações na ordem industrial. A Revolução Industrial na França iniciou-se em $1825 \mathrm{com}$ a derrota napoleônica, que fêz com que desaparecessem da França as máquinas têxteis de algodão e metalúrgicas modernas, tornando a agricultura predominante, ligada à escassez

de alguns produtos in natura, à falta de mão-de-obra especializada e escassez de capital.

Sob influência de Turgot (17741776) tendem-se a destruir os privilégios das guildas para liberalizar a indústria. Com a lei Chapelier, de 14 de junho de 1791 , declarando ilegais as reuniōes dos operários, "pois pretendiam restabelecer os privilégios das antigas corporações eliminadas pela Revolução Francesa", criam-se as condições ao desenvolvimento do capitalismo liberal.

A Revolução Industrial na Alemanha deu-se de forma incompleta e gradualmente devido à predominância do trabalho manual e a persistência das pequenas oficinas. Até a segunda metade do século XIX, a Alemanha estava industrialmente retardatária, a agricultura constitula a principal ocupação da população. Até 1850, as máquinas eram escassas, pois predominava o sistema de trabalho domiciliar; o país era pobre devido à persistência de um sistema de guildas e à falta de um Estado centralizado. A Alemanha estava dividida em 39 estados diferentes, o que impedia seu desenvolvimento industrial. Ela carecia de mercado interno e não possuia colônias. A invasão francesa ofereceu à Alemanha a possibilidade de passar do estágio do monopólio das guildas ao sistema industrial liberal; entre 1868 e 1869, surge uma legislação que legaliza a liberdade industrial; os trabalhadores tiveram então liberdade para oferecer sua mão-de-obra no mercado, sendo removidos todos os obstáculos ao desenvolvimento industrial.

A União Aduaneira Alemã permitiu a ampliação do mercado. Com o surgimento do sistema ferroviário estendiam-se mais os limites do mercado alemão. A Alemanha, além de importar máquinas da Inglaterra, importara mão-de-obra com a emigração de trabalhadores especializados inglêses integrados nas áreas industriais da Alemanha.

$\mathrm{Na}$ Inglaterra, a primeira indústria totalmente mecanizada foi a têxtil, no seu ramo algodoeiro com a introdução da máquina de fiar automática de Hargreaves, a máquina hidráulica de Arkright, a mule de Samuel Coompton, que permitia a produção de um fio duro e fino e Cartwright inventara o tear mecânico; isso levou ao declínio do artesanato e ao aumento do contingente operário. Acresce $o$ invento de Whitney que, em 1794, conseguiu por meios mecấnicos a separação da semente de algodão da fibra que, por via manual, era lenta e complicada. Whitney obteve por meios mecânicos essa separação, determinando uma revolução na indústria algodoeira e do setor agrícola, conduzindo a especialização do Sul dos EUA nesse ramo, estimulando assim a expansão da escravidão.

A máquina têxtil e a máquina a vapor produziam a fôrça motriz. Tôda essa maquinaria necessitava de grande quantidade de ferro a preço baixo, fato que levou a substituição do carvão de madeira que desflorestava grandes áreas, pelo carvão coque aliado ao alto forno de Smeaton com o método Bessemer. Paralelamente, a extração de carvão tornou-se mais segura quando Davy inventa a lâmpada de segurança nas minas, diminuindo a freqüência das mortíferas explosões de gás

¿s Num sentido contrário, defendendo a tese do incremento da Revoluçăo Industrial por trans!erência de renda do setor agrario ao industrial. Bairoch, Paulo. La revolutión industrial y el subdesarrolio. revolutión industrial y el subdesarrol 
no interior das minas, tendo o método Siemens-Martin superado o método Bessemer no fabrico de aços finos.

Essa infra-estrutura tecnológica acompanha a emergência do sistema fabril, que consiste na reunião de um grande número de trabalhadores numa só fábrica, disciplinando o operário. A inspeção realizada pelo capitalista atua na fábrica, disciplinando o operário. De início temporária e esporádica, por ocasião da distribuição de matéria-prima e recolhimento do produto acabado, transforma-se na presença constante no processo fabril. Assim, o tecelão que chegasse cinco minutos após 0 , último sinal ou que deixasse algum resíduo nos fusos, assobiasse ou deixasse aberta a janela era multado em 1 xelim por cada contravenção. ${ }^{49}$

As condições de habitação igualavam nos seus aspectos negativos às condições de trabalho, onde o parcelamento das operações produzia a fadiga, tédio e surmenage. Os novos centros industriais abrigavam trabalhadores em choças preparadas precipitadamente. ${ }^{00}$ Três quartas partes dos trabalhadores de fábrica de algodão eram mulheres e crianças que trabalhavam nas máquinas, os aprendizes mendigos que abundavam na Inglaterra eram empregados como arrendados pelas autoridades às manufaturas, com jornadas de trabalho de 14 a 16 horas diárias.

Os fiadores de algodão de Manchester, em 1806, ganhavam por semana em média 24 xelim; só em 1897, alcançaram 37 xelim. Isso representa um desnível em relação ao incremento da renda da emprêsa capitalista inglêsa. No século $X I X$, "embora subissem ligeiramente os salários, os trabalhadores não especializados na Inglaterra mantinham-se na base do salário mínimo vital, e, às vêzes, abaixo do mesmo, abrangendo $31 \%$ da população londrina, vivendo abaixo da linha da pobreza". ${ }^{51}$

A situação nas minas não era melhor; mulheres e crianças eram empregadas, de 12 a 16 horas por dia, em poços subterrâneos. Isso obrigou o Estado a intervir nas relações industriais, regulamentando as horas de trabalho: no ano de 1874, a idade minima de trabalho era de 10 anos e a jornada máxima de 10 horas. Na Alemanha, a partir de 1891, tornou-se ilegal a contratação de uma criança que não tinha terminado sua escolaridade mínima aos 13 anos. A partir de 1901, a idade mínima de uma criança apta ao trabalho era de 14 anos e a jornada máxima, de meia jornada de trabalho de um total de 12 horas. ${ }^{52}$

A resposta à Revolução Industrial na Inglaterra, França e Alemanha será fornecida pelos teóricos, Saint-Simon, Proudhon, Fourier e Marx que contestarão a nova ordem de coisas num nível global, ou seja, na procura de um modêlo de sociedade global que seja a negação daquela que emergiu com a Revolução Industrial.

Saint-Simon, na sua obra L'organizateur (1819-20) prenuncia a noção de uma direção científica confiada a um govêrno constituído de três câmaras: Invenção, Exame e Executiva, constitulda de líderes industriais, capitalistas e banqueiros. "A inoculação política de vasta maioria da sociedade existe para ser governada da maneira mais barata possível, quando possivel; governada pelos homens mais capazes e de maneira que se assegure a mais completa tranqüilidade pública. Ora, os mesmos meios de satisfazer nestes vários aspectos, ao desejo da maioria, consistem em conferir poder aos mais importantes industriais, que são os mais interessados na economia das despesas públicas, os que são os maiores interessados em restringir o poder arbitrário; finalmente, de todos os membros da sociedade são os que mais têm dado prova de capacidade na administração positiva, tendo sido evidenciado o sucesso que obtiveram em seus vários empreendimentos". ${ }^{53}$

Saint-Simon elabora a primeira crítica de conteúdo a respeito da emergência do modêlo

liberal, ao enunciar que a "Declaração dos Direitos do Homem e do Cidadão, vista como a solução do problema social, na realidade era o seu primeiro enunciado". ${ }^{54}$ Elle não perde de vista que o desenvolvimento industrial leva a superar um tipo de saber jurídico - formal, que desconhece o econômico, "a inferioridade dos legistas é sua ignorância do econômico, isto é, da produção, partindo dos interêsses que são os da maioria de um regime moderno que é industrial".

Após definir que os produtores constituem a sociedade legítima, postula a afinidade dos interêsses da indústria com a sociedade, na medida em que a sociedade global tem por base $a$ indústria. A indústria é uma garantia de sua existência. O contexto mais favorável à indústria será o mais favorável à sociedade. ${ }^{56}$ A sociedade moderna "só dá direito de pertencer a eia, os trabalhadores"; $^{57}$ eis que a classe trabalhadora "deve ser a única". 58 Saint-Simon, "o cérebro mais universal de seu tempo, com Hegel", 59 enunciava que é "pelo estudo direto e positivo da sociedade que se descobrirão essas regras (da vida social); nelas

\footnotetext{
4 Hamon, J. L. B.; \& Barbara. The town labourer.' Longmans, 1925. p. 19-20. 
é que é necessário descobrir as bases da política". ${ }^{60}$

Saint-Simon ocupa uma posiçãochave entre os teóricos das ideologias totais na época imediatamente posterior à Revolução Industrial, pois êle "ajudou a transformação da sociedade nessa arte que se chamará - socialismo, nessa ciência popular em que Adam Smith e David Ricardo definiram sua fórmula básica: o valor tem por medida o trabalho". ${ }^{61}$

Fourier, teórico socialista, é considerado atualmente um predecessor das técnicas de dinâmica de grupo, considerando a emprêsa como "grupo". Tendia Fourier a ver, na marcha da sociedade, o caminho para - estabelecimento de uma harmonia universal, a partir do contrôle das paixões humanas. Estabelece Fourier uma solidariedade básica entre a sociedade global e os padrões educacionais, ao admitir que um coletivismo social leva a uma pedagogia não individualista. Inicialmente, Fourier ataca a declaração dos Direitos do Homem e do Cidadão, oriunda da Revolução Francesa, ao denunciá-la como "uma Carta incompleta e desprezível, porque omitiu o Direito ao Trabalho, sem o qual todos os outros são inúteis". ${ }^{2}$ Teve ela 0 condão de "produzir um tal caos político que é de se admirar se o gênero humano pôde regredir muitos milhares de anos na sua evolução social". ${ }^{83}$ concluindo Fourier que "não há nada a esperar de tôdas as luzes adquiridas; é necessário procurar o bem social em alguma nova ciência". ${ }^{64}$ Só ela trará a felicidade à humanidade, pois é evidente que "nem os filósofos, nem seus rivais sabem remediar as misérias sociais e, sob os dogmas de uns e outros, vê-se a perpetuação das chagas mais tristes, entre outras, a indigência". ${ }^{65}$ Combatendo a pobreza como "a mais escandalosa desordem social", ${ }^{66}$ visualizando a civilização como "a guerra do rico contra o pobre" e para sair dêsse estado de coisas, Fourier apresenta uma fórmula e antecipa o fato de que "é a mim sòmente que as gerações presentes e futuras deverão a iniciativa de sua imensa felicidade; venho dissipar as nuvens políticas e morais e sơbre os dogmas das ciências naturais, eu fundamento a teoria da harmonia universal". ${ }^{68}$

A sociedade futura, que irá suceder à "incoerência" civilizada, não admite "moderação, igualdades, nem pontos de vista filosóficos. Ela quer as paixões ardentes e fecundas; desde que a associação está formada, elas se articulam mais fàcilmente, quanto mais vivas forem, mais numerosas". ${ }^{69}$ Fourier antevê uma sociedade onde "as jornadas de trabalho serão curtas, o trabalho será variado, parcelado".70 Surgirá uma sociedade natural onde "os Falanstérios (comunidades) se agruparão por influência de suas paixões, gostos e caracteres. A ordem nascerá naturalmente, espontâneamente do jôgo das atrações". 71

$\mathrm{Na}$ sua teoria social total, Fourier vê o elemento afetivo como fator de solidariedade social, estruturando "a concepção social das paixões humanas". 72 Elas desenvolverão o espírito dos agrupamentos sociais, levando "a economia de tempo, matériasprimas, maior rendimento, menor fadiga, desaparecimento do desprêzo do rico pelo pobre. Não haverá vagabundos, nem pobres, as antipatias sociais desaparecerão com as causas que as engendram". ${ }^{73}$ 0 estabelecimento de tal sociedade perfeita demanda, para Fourier, um prazo curto, "dois anos para sua organização como cantão societário - sua expansão pelo mundo levará mais tempo - seis anos para organizá-lo pelo globo". ${ }^{74}$

Fourier com Saint-Simon é um dos últimos representantes dos propugnadores por soluções sociais globais a curto prazo. Sua descrição paradisíaca do futuro liga-se à crítica acre da sociedade de sua época, levando-o à concepção de que "uma sociedade só pode decair em função do progresso social". ${ }^{75}$

\subsection{A teoria de Karl Marx}

O marxismo aparece como filosofia da ação, ${ }^{76}$ onde a vontade humana tem um papel criativo, superando as determinações ambientais, 77 para conseguir a constituição do proletário como classe, derrubada da supremacia da burguesia e conquista do Poder. ${ }^{78}$

Eis que, para Karl Marx, a condição essencial de existência da burguesia é a formação e crescimento do capital, condição básica para a luta de classes, que caracteriza o processo da história, ${ }^{79}$ no qual a burguesia desempenhou um papel revolucionário. Ela liquidou as relações feudais e patriarcais, definiu, pela exploração do mercado mundial, um caráter universal às relações de produção e troca, submeteu a área rural à urbana e efetuou a centralização política. ${ }^{80}$

Denunciando porém, Karl Marx, a estreiteza das estruturas criadas pela burguesia para conter a riqueza em seu seio, ${ }^{81}$ a

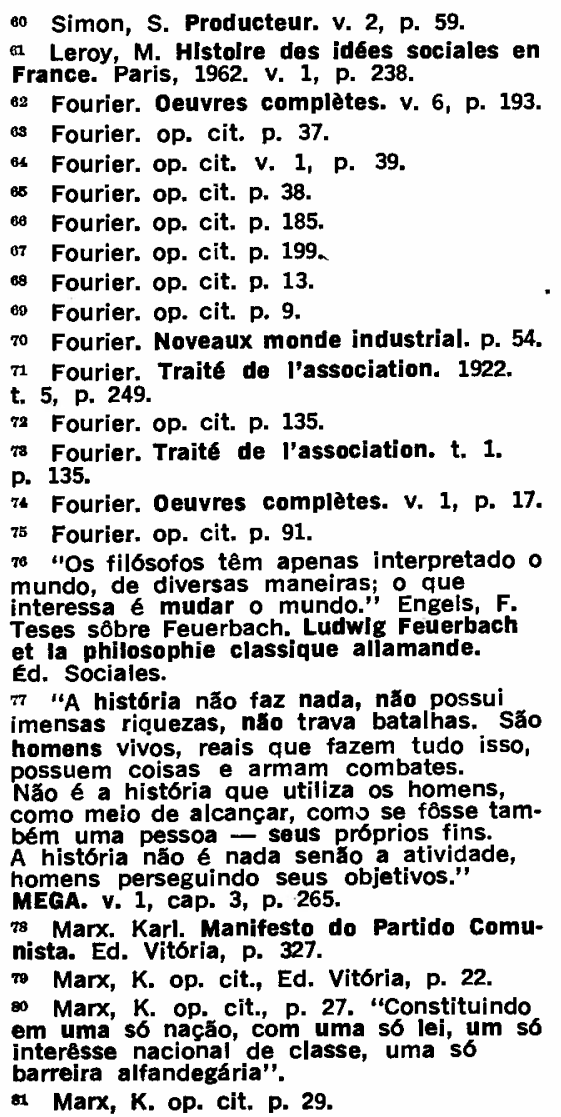

6o Simon, S. Producteur. v. 2, p. 59.

en Leroy, $M$. Histoire des idées sociales en

as Fourier. op. cit. p. 37.

a Fourier. op. cit. v. 1, p. 39

Fourier, op. cit. p. 38.

Gourier. op. cit. p. 199.

6o Fourier. op. cit. p. 9

70 Fourier. Noveaux monde industrial. p. 54.

71 Fourier.

72 Fourier. op. cit. p. 135

p. 135

74 Fourier, Oeuvres complètes. v. 1, p. 17

75 Fourier. op. cit. p. 91.

7 "Os filósofos têm apenas interpretado mundo, de diversas maneiras; o que

Teses sôbre Feuerbach. Ludwig Feuerbach et la philosophie classique allamande.

77 "A história não faz nada, năo possu imensas riquezas, nto trava batalhas. Săo homens vivos, reais que fazem tudo isso possuem coisas e armam combates. como meio de alcancar, como se fôsse tambem uma pessoa - seus proprios fins. A historla nâo e nada senao a atividade, MEGA. v. 1, cap. 3, p. 265.

nista. Ed. Vitoria, p. 327.

79 Marx, K. op. cit., Ed. Vitória, p. 22 8 Marx, K. op. cit., p. 27. "Constituindo interesse nacional de classe, uma só

ol Marx, K. op. cit. p. 29 
própria burguesia criou seus opositores: os operários, concluindo que a queda e a vitória dêstes são igualmente inevitáveis. ${ }^{82}$

Karl Marx elaborou, em suas grandes linhas, uma filosofia de conflito social, estruturando uma visão da sociedade global cujas premissas são os homens, no seu processo de vida em sociedade. ${ }^{83}$ Nela, o trabalho aparece como grande fator de mediação que enriquece o mundo de objetos tornado poderoso, ao lado do empobrecimento "em sua vida interior" de trabalhador, onde êste não é dono "de si próprio". ${ }^{84} 0$ fruto do trabalho aparece como um "ser estranho com um poder independente do produtor", 85 onde as relações mútuas dos produtores tomam a forma de uma "relação social entre coisas". ${ }^{86}$

A industrialização promove nova estratificação social: as classes médias aparecem como elemento conservador do sistema. ${ }^{87}$ 0 lúmpen proletariado, embora sujeito a acompanhar o proletariado, por suas condições de vida "predispõe-se mais a vender-se à reação", 88 "cristalizam uma formação social onde a emancipação do operário como classe, implica a libertação da sociedade global". ${ }^{89}$

Karl Marx fornece uma visão sociológica finalista, que perpassa seu pensamento no nível de modelos macrossociais, surgindo como reação ao desafio da Revolução Industrial inglêsa, onde a divisão manufatureira do trabalho como combinação de ofícios independentes, implica a concentração do processo produtivo, criando estruturas "reificadoras" do homem. Ao lado da importância atribuída à fábrica como instituição decisiva da sociedade industrial, Marx incidentalmente aborda o processo de burocratização da emprêsa, ${ }^{90}$ a patologia industrial, ${ }^{91}$ sem porém, desenvolver sistemàticamente uma teoria da organização.

\section{TERCEIRA FASE DA INDUSTRIALIZAÇAOO}

Ela se inicia com a decadência dos ofícios tradicionais. Os ofícios qualificados subdividemse, especializam-se, embora outros ofícios, que continuam qualificados, percam parte de seus valôres. Os novos ofícios estão na dependência de uma máquina que sofre aperfeiçoamento contínuo. ${ }^{92}$ A maquinaria específica dessa nova divisão de trabalho é o trabalho coletivo, como continuidade dos trabalhos parciais.

A especialização impede que 0 aprendiz passe a ajudante $e$ êste a companheiro; o trabalho como elemento de ascensão social implicará a "educação permanente".

A equipe de trabalhadores em torno de uma pessoa, um oficial com experiência, desaparece, na medida em que o cálculo substitui a experiência, mediante análise no Departamento de Métodos; efetua-se assim a separação entre concepção e execução do trabalho na emprêsa. A indústria têxtil adota inicialmente êsses métodos; paralelamente, a indústria de construção naval conserva o sistema profissional de trabalho.

O aumento da dimensão da emprêsa no período da segunda Revolução Industrial, além de ocasionar uma mutação, onde as teorias sociais de caráter totalizador e global (Saint-Simon, Fourier e Marx) cedem lugar às teorias microindustriais de alcance médio (Taylor, Fayol), implica, no plano da estrutura da emprêsa, a criação "em grau maior ou menor de uma direção determinada, que harmonize as atividades individuais e que realize as funções gerais que derivam da atividade do corpo produtivo no seu conjunto". ${ }^{93} 0$ crescimento da dimensão da emprêsa irá separar funções de direção, de funções de execução. ${ }^{94}$ Dá-se assim, a substituição do capitalismo liberal pelos monopólios. Entre 1880/90, nos Estados Unidos, instala-se a produção em massa, - número de assalariados aumenta em 1.500 mil, é necessário evitar-se o desperdício e economizar mão-de-obra.

\subsection{Os fundamentos quaker do sistema Taylor}

Taylor, oriundo de uma família de quakers, ${ }^{95}$ foi educado na observação estrita do trabalho, disciplina e poupança. Educado para evitar a frivolidade

82 Marx, K. op. cit. p. 37.

83 "A consciência jamais poderá ser alguma coisa além da existência consciente e a existência dos homens é o seu processo de vida atuante." MEGA. v. 1. cap. 5, p. 15-17.

84 MEGA. v. 1, cap. 3, p. 83-84.

85 MEGA. v. 1, cap. 3, p. 83.

os Marx, K. El capital. v. 1, p. 7778.

87 Marx, K. Manifesto... p. 34.

o8 Marx, K. Manifesto... p. 34.

80 ".... Pois ela é uma perda total da humanidade; em suma, ela, a classe operária s6 pode redimir-se por uma redenção total da humanidade." MEGA. v. 1, cap. 1 , p. 617-21.

so Marx, K. El capital. v. único, cap. 12. p. 244 e 261 .

2 Marx, K. op. cit. cap. 12, p. 266-67.

92 “'A manufatura desenvolve a produção em série, cada trabalhador tem uma função parcial, ela se decompõe em inúmeros antigos ofícios." Marx, K. EI capital. cap. 12, p. 255.

2s "Um violinista não precisa diretor precisa-o o conjunto." Marx K. EI capital. p. 242.

04 A funcão inspetora direta e contínua do trabalhador ou grupos de trabalhadores passa a ser agora a funçăo de uma classe especial de assalariados. O trabalho de vigilância transforma-se em funçāo executiva dessas pessoas." Marx, Karl. op. cit. cap. 11, p. 243 .

-5 "Ainda mais notável, pois apenas deve ser lembrada a relação entre uma filosofia religiosa de vida com o mais intenso desenvolvimento da mentalidade comercial, justamente no rol daquelas seitas cujo alheamento da vida se tornou tão proverbial quanto sua riqueza, principalmente entre os quakers e menonitas.

o papel que os primeiros tiveram na Inglaterra e América do Norte, coube aos segundos, nos Países Baixos e Alemanha." Weber, Max. A ética protestante e o espírito capitalista. Ed. Pioneira, 1967, p. 26. Max Weber constata que a tendência das minorias religiosas, privadas de poder político, é "envolverem-se em atividades económicas". Isto se deu "com os năoconformistas e quakers na Inglaterra". conformistas quakers na Inglaterra". do ascetismo protestante, parte importante ao lado de outras seitas como "os batistas, menonitas, coube principalmente aos quakers". Weber, Max., op. cit. p. 102 $A$ idéia de que Deus fala sỏmente quando as criaturas silenciam significou uma formaço tendendo "para a tranqüila ponderaçzo dos negocios, para orientaçáo destes em têrmos de cuidados - justíficaç̃o da consciência individual." Weber, Max. op. cit. p. 106. 
mundana, ${ }^{\theta 6}$ converteu o trabalho numa autêntica vocação. ${ }^{97}$

Iniciou sua vida profissional como operário da Midval Steel Co., passando a capataz, contramestre e chefe de oficina, daí a engenheiro.

O estudo do tempo, a cronometragem definem-se como pedra angular de seu sistema de "racionalização" do trabalho.

Cada operação é decomposta em "tempos elementares"; auxiliado pelo cronômetro, Taylor determina o tempo médio para cada elemento de base do trabalho, agregando os tempos elementares e mortos, para conseguir o tempo total do trabalho, com a finalidade messiânica 98 de evitar o maior dos pecados - a perda de tempo. A finalidade maior do sistema é educativa e manifesta-se pela intensificação do ritmo de trabalho. ${ }^{90}$ Para introduzir seu sistema, Taylor promove uma cruzada contra as "idéias falsas", o empirismo, ${ }^{100}$ preconizando a prioridade do sistema sôbre o indivíduo, criticando, em nível quaker, o pecado da idolatria do "grande iluminado". 101 A prioridade do seu método abrirá um ciclo de prosperidade. 102

0 messianismo administrativo de Taylor parte da função providencial do empresário, ${ }^{103}$ que existe para satisfazer os interêsses gerais da sociedade e o particular do consumidor. Isso motiva a coletividade ao aproveitamento intensivo de suas riquezas, que a Providência colocou sob seu poder, racionalizando sua conduta, sua vida diária. 104

Há em Taylor, uma paideia, um ideal de formação humana de um tipo de personalidade, conseqüência lógica da aplicação e vivência do sistema da Administração Científica do Trabalho. Tem seu sistema o mérito de acentuar a virtude do ascetismo, ${ }^{105}$ a mentalidade en- tesouradora no que se refere a dinheiro, ${ }^{106}$ a abstinência de álcool, 107 trabalho constante ${ }^{108}$ com "a figura do chefe enérgico, paciente e trabalhador" (Taylor) que incita a ambição do subordinado, condena a negligência e dissipação. ${ }^{100}$ No plano salarial, mercê de sua atitude pessimista ante a natureza humana, 110 Taylor manifesta-se favorável a baixos salários, ou. melhor, seu aumento deve ser dosado gradativamente.

No plano de sua Teoria da Administração, Taylor define a burocracia como emergente das condições técnicas de trabalho, pela separação entre as funções de execução e planejamento, predominando a organização sôbre o homem, acentuando

* Evitar a "vaidade mundana, seja toda ostentação, frivolldade, e uso das coisas
sem propósitos práticos, ou que forem valiosem propósitos práticos, ou que forem val sas apenas por sua raridade, qualquer uso não consciencioso da riqueza, tal nāo muito urgentes, e acima da provisáo necessária das reais necessidades da
vida e do futuro". Weber, Max. op. cit vida e do
p. 218-19.

n A gravidade de sua vida, seu entusiasmo reformista pela substituição do empirismo pela ciência (Taylor. op. cit. p. 94) têm profundas ralzes na sua formaçáo familiar, onde encontrou "ambiente de pureza de vida sã de ideal de emancipaçăo humana não so no aspecto moral, como também no intelectual, político e social". Mallat y Cuto, Jose. Organización cientr.ica del trabajo. Espanna, Ed. Labor, 1942, p. 11-12.

a "Indicar por meio de uma série de exemplos a enorme perda que o país vem sofrendo com a ineficiência de quase todos os nossos atos diários". Taylor. op. cit. p. 11.

- "Aperfeiçoar o pessoal da empresa para que possam executar em ritmo mais rápido e mais eficiente, os tipos mais elevados de trabalho, conforme suas apti100 "Os conhecimentos e métodos cientificos a serviço da administração,

substituirão em tôda parte mais cedo ou mais tarde, as regras empiricas, porquanto é impossivel o trabalho cientitico com os antigos sistemas de administração."

101 "O remédio para essa ineficiência está antes na administração que na procura do homem excepcional ou extraordinário." Taylor. op. cit. p. 11. Essa atitude antifidolatrica transportada para sistema folítico é que explica como o protestantismo na medida em que cond a idolatria das pessoas, constitui-se em antídoto à obediêncía passiva a um Iideres carismáticos totalitários, cria um ethos democrático com
fiança do grande lider.

100 Sob "a administração cientifica, as fases intermediárias seráo mais prósperas - mais felizes, livres de discórdia $\theta$ dissensóes. Támbém os perlodos de infortánio serao em menor número, mais curtos a menos atrozes". Taylor. op. cit. p. 29.
200 Em Taylor dá-se a valorizaçăo positiva da indústria, da funçåo do trabalho do empresário no sistema social global.

Isso se deve à sua formação quaker. Pertencendo a uma das inćmeras seitas da Igreja Reformada que auto-excluiu-se da cidadania politica ao "recusar-se a prestar serviço militar, Inabilitando-se, portanto, à nomeação para os cargos páblicos" (Weber, Max. op. cit. p. 107), ela acompanha assim "o destino das seitas marginalizadas, ao fortalecer a tendencia a envolver-se com particular empenho nas atividades económicas".

Weber, M. op. cit., p. 22. Dal a emergéncla de um quaker preocupado com a administração científica da emprêsa, onde o empresário tem uma funçąo providencial:

"sua prosperidade consequência do uma vida santa" (Weber, M. op. cit. cap. 5, p. 21), onde se concilia "auferlr lucros e conservar-se piedoso" (Weber, M. op. clt. cap. 5, p. 209, nota 39); como se dá a conciliaçăo da administração cientifica com o misticismo "a administração cientifica não pode existir se não existe ao mesmo tempo um certo estado de espirito, o qual o engenheiro (Taylor) define em têrmos quase místicos", Taylor. L'organization scientifique dans I'industrie americaine. Societé Taylor, Paris, Ed. Dunod, 1932, Taylor, p. 11.

104 O escrápulo de sua conduta é para o batista funçāo da "maior glória de Deus'" (Weber, M. op. cit. p. 79-80), "pertence esfecialmente ao quaker a conduta do homem tranqüilo, moderado eminentemente consciencioso" (p. 106).

106 "O ascetismo quaker desenvolverá o sentimento religioso da vida com o mais intenso desenvolvimento da mentalidade co mercial" (Weber, M. op. cit. p. 26); isso levou-o a dar um "significado (p. 53) onde êle aparece como a mais alta expressão de "amor ao próximo" (p. 54).

200 "O carregador de lingotes de ferro tinha fama de ser seguro" (Taylor. op. cit. p. 66), isto é, "dá muito valor ao dinheiro, um centavo parece-lhe tão grande como uma roda de uma carroca". (Taylor. op. cit. p. 42). Os operários que foram aumentados "comecaram a economizar dinheiro" (p. 66), cumprindo os preceitos puritanos de Benjamin Franklin que enunciara: "Lembra-te que o dinheiro 6 por natureza prolífica, procriativa. O pode gerar mais e assim por diante". Weber, Max. op. cit. p. 30 .

107 A condenação do álcool é um dos elementos do puritanismo; por essa razso, os escoceses estritamente puritanos e os independentes ingleses foram capazes de manter o probo (de bébado) não devia ser batizado". Weber, Max. Op. cit. p. 167. nota 21 .

100 "De acordo com a ética quaker a vida profissional é uma prova de seu estado de graça que se expressa no zélo e método, fazendo com que cumpra sua vocação. Não é um trabalho em si, mas é pedida por Deus". Weber, M. op. cit. p. 115.

109 Para o quaker a vida profissional do homem define seu estado de graça, para, sua consciéncia que se expressa no zélo".

"a vadiação é o maior mal". Taylor. p. 74.

110 "Quando recebiam mais de $60 \%$ do seu salário muitos deles trabalhavam irregularmente $e$ tendiam a ficar negligentes, extravagantes e dissipadores. Em outras palavras, nossas experiencias demonstraram que para a maioria dos homens não convém enriquecer depressa" (Taylor. op. cit. p. 68), confirmando as afirmaçōes contidas no calvinismo secula. rizado pelo protestantismo holandes "ao afirmar que as massas so trabalham quando alguma necessidade $a$ isso as force" (Weber. op. cit. p. 128). 
como fator motivacional único, o monetário. ${ }^{111}$

Taylor parte de um ponto de vista segundo o qual o interêsse dos trabalhadores é o da administração, desconhecendo as tensões entre a personalidade $e$ a estrutura da organização formal.

A análise de tempos e movimentos, base do taylorismo, se por um lado foi recebida com agressividade pelos operários da indústria em geral e pelos da American Federation of Labor, por outro foi entusiàsticamente defendida por Le Chateller que compara Taylor a "Descartes, Bacon, Newton e Claude Bernard". ${ }^{112}$

Taylor procura fazer com que os operários possam executar em "ritmo mais rápido, os mais pesados tipos de trabalho". ${ }^{113}$ Para isto seleciona para seus testes, dois dos melhores trabaIhadores, isto é, atípicos que "por sua robustez física tinhamse revelado dedicados e eficientes", 114 sendo, porém, os de menor "nível mental". ${ }^{115}$ Está claro que Taylor não toma como base o operário médio, valorizando um tipo de fadiga, a muscular, desconhecendo a fadiga mais sutil, a nervosa.

Quanto aos tempos, verificou-se posteriormente ser impossivel decompor minuciosamente uma operação em seus elementos, de forma que os tempos correspondentes sejam sempre úteis. O chamado tempo "morto" tem um papel positivo, qual seja, de restabelecer a energia perdida para a continuidade do processo produtivo. Por outro lado, o aumento de produtividade, apresentado por Taylor como um dos resultados do sistema nôvo, na medida em que êle tem como elemento motivador o aumento salarial, é difícil saber se êste se deve à nova técnica de trabalho ou ao prêmio.
0 estudo dos movimentos depende das dificuldades individuais e a velocidade não é o melhor critério para medir a facilidade com que o operário realiza a operação. Seu método representa uma intensificação e não racionalização do processo de trabalho. ${ }^{116}$ Hoje, solicitamse rendimentos ótimos, não máximos.

Taylor estudou o trabalho pesado, não qualificado, com a pá, 117 trabalho de fundição 118 e de pedreiro, ${ }^{119}$ daí sua preocupação com a fadiga muscular e seu desconhecimento da fadiga nervosa. Alie-se a uma visão negativa do homem, onde os indivíduos nascem preguiçosos e ineficientes, ${ }^{120}$ infantilizados $^{121}$ e com baixo nivel de compreensão. ${ }^{122}$ Com essa visão do homem, êle define o papel monocrático do administrador. ${ }^{123}$

A separação entre direção e execução, autoridade monocrática, acentuação do formalismo na organização, a visão da administração, como possuidora de idênticos interêsses ao operário, definem o ethos burocrático taylorista, complementado por Fayol.

Fayol, seguindo a linha de Taylor, defende a tese segundo a qual o homem deve ficar restrito a seu papel, na estrutura ocupacional parcelada. ${ }^{124}$

No plano da remuneração, manifesta-se contra a ultrapassagem de certos limites, ${ }^{125}$ comparando a disposição estática das ferramentas na fábrica com os papéis das pessoas na organização social, 1:60 reafirmando a monocracia diretiva, ${ }^{127}$ combinada com um tratamento paternalista do operário, ${ }^{128}$ concluindo que administrar é prever, organizar, comandar e controlar.

Elemento básico na teoria clássica da administração, em Taylor e Fayol, é o papel conferido à disciplina copiada dos modelos das estruturas militares. ${ }^{129}$

Os modelos administrativos Taylor-Fayol correspondem à divisão mecânica do trabalho (Durkhein), onde o parcelamento de tarefas é a mola do sistema. Daí ser importante nesse sistema que o operário saiba muito a respeito de pouca coisa. No referente à remuneração, Fayol continua a tradição quaker de Taylor - não pecar por excesso.

111 "E preciso dar ao trabalhador o que êle mais deseja: altos saĺ́rios" (Taylor. op. cit. p. 14)

112 Ramos, G. Sociologia industrial. p. 127.

113 Taylor. op. cit. p. 15.

114 Taylor. op. cit. p. 51.

w6 "Um dos requisitos para que o indivíduo possa carregar lingotes como ocupação regular é ser tão estúpido e fleumático"

(Taylor. p. 58). Há precedente histórico a respeito da utilização nd indústria de pessoas de baixo nivel mental: "nos meados do século XVIH, algumas manufaturas empregavam para certas operaçes simples, que constituiam segredos de produção, de preferencia pessoas semiprodução, de preferencia pessoas semipastas and present s. D. A history of the population. London, 1846. v. 1, p. 149 .

Esse período oferece material para elaboraça de uma pato.ogia industrial que çáo de uma pato.ogia industrial que Meignez. La patologie sociale de l'entreprise. Paris, Ed. G. Villars.

110 Taylor. op. cit. p. 106

117 Taylor, op. cit. p. 61.

118 Taylor. op. cit. p. 44.

10 Taylor. op. cit. p. 77

200 Taylor. op. cit. p. 29

t21 Taylor. op. cit. p. 89.

122 Taylor. op. cit. p. 89.

128 Taylor. op. cit. p. 75. "A atribuição de impor padrões e forçar a cooseração compete exclusivamente à direção".

124 Fayol, H. Administração industrial geral. São Paulo, Editôra Atlas, 1960. p. 31. "Cada mudança de ocupação, de tarefas implica num esfórço de adaptação que diminui a produção."

125 Deve-se "evitar o excesso de remuneracão, ultrapassando o limite razośvel". Fayol. op. cit. p. 39.

120 "Um lugar para cada coisa, cada coisa e cada pessoa no seu lugar". Fayol. op. cit. p. 51

127 Fayol. op. cit. p. 51.

198 Fayol. op. cit. p. 54.

120 "Nāo necessita de demonstraçăo espe cial o fato de que a disciplina militar" foi o padrão ideal das antigas implantaç̃es, como das emprêsas industriais capitalistas "modernas". Weber. Economía y sociedad. vol. 4, cap. 5, p. 80 . Essa visão é integrada no corpo da Teoria Clássica da Âdministraçăo quando Fayol define que "isso tem sido exuresso com grande vigor" " na área da emprêsa. Fayol. op. cit vigor. 
Ao enfatizar a função exemplar do administrador êle define as linhas essenciais do burocratismo de organização formal.

No fortalecimento dos chefes de oficina e contramestre por um Estado Maior, ${ }^{130}$ enfatiza êle o papel da disciplina estrita na organização fabril. Define êle a linha de pensamento que 0 Coronel Urwick irá acentuar no paralelismo entre a organização militar e a industrial.

Esse paralelismo já fôra objetivo de estudo de Max Weber. ${ }^{131}$ Com efeito, a guerra criou, à sua maneira, um tipo de diretor industrial, integrando o engenheiro civil, mecânico e marítimo. Por outro lado, o exame topográfico, o uso dos mapas, planos de campanhas, prefigura o conceito atual de "campanha" publicitária. As condições de transporte, intendência, divisão de trabalho entre cavalaria, infantaria e artilharia, a divisão dos processos produtivos entre essas três armas, define que a mecanização se dera antes na área militar e posteriormente na manufatura industrial. $A$ mecanização industrial como sistema permanente, sempre tendeu a copiar os modelos militares. Por influxo de um militar, Napoleão III, foi oferecida uma recompensa a quem inventasse um processo barato para o aço, capaz de suportar a fôrça explosiva de novas bombas. Daí surgiu o processo Bessemer.

Não é necessário acentuar que a demanda de uniformes para o exército - realçada por Sombart - foi a primeira em grande escala de mercadorias padronizadas.

Porém, isso implica um alto nível de burocratização e formalismo organizacional.

O esquema Taylor-Fayol aparece como um processo de impessoalização, definida esta pelo enunciado de tarefas ${ }^{132}$ e especialização das mesmas; as pessoas se alienam nos papéis, êstes no sistema burocrático.

A decisão burocrática é absolutamente monocrática, só há um fluxo de comunicação. 0 empregado adota os mitos da corporação, que constitui uma atribuiçã̃o de status e ao mesmo tempo cria-se um jargão administrativo esotérico. ${ }^{133}$

Conclusivamente os esquemas Taylor-Fayol fundam-se na justaposição e articulação de determinismos lineares, fundados numa lógica axiomática que cria um sistema de obrigação devido à lógica interna.

Dal operar uma racionalidade em nível de modêlo, onde as operações de decomposição $e$ análise, fundadas em aspectos microeconômicos, criam um sistema de coordenação de funções, donde emerge uma estrutura altamente formal. Seu comando é centralizado, fundado numa racionalidade burocrática, baseada na racionalização das tarefas, sua simplificação e intensificação do trabalho.

A mudança das condições de trabalho leva à mudança dos modelos administrativos.

A evolução do trabalho especializado, como situação transitória entre o sistema profissional e o sistema técnico de trabalho, a desvalorização progressiva do trabalho qualificado e a valorização da percepção, atenção, mais do que da habilidade profissional, inauguram a atual era pós-industrial.

O conjunto volta, na emprêsa, a ter prioridade sôbre as partes quando ela alcança alto nível de automação. Efetua-se a mudança do operário "produtivo" para o de "contrôle". A nova classe operária vai caracterizarse pelo predomínio de funções de comunicação, ${ }^{134}$ sôbre as de execução.

Numa fábrica automatizada torna-se impossivel manter a ficção de uma hierarquia linear simples (modelos Taylor, Fayol); são necessários especialistas funcionais que devem comunicar-se entre si. 0 princípio organizacional não se estrutura na hierarquia de comando; êle se define na tecnologia que requer a cooperação de homens de vários níveis hierárquicos $\mathrm{e}$ qualificações técnicas.

O operário de contrôle, nesse sistema, só poderá ser considerado um elemento qualificado, na medida em que lograr descodificar os sinais observados. 0 sistema técnico de trabalho liga-se às formas de organização. Dal a possibilidade de uma divisão de funções mais dinâmica.

A elevação do nível de cultura e o abandono do nível taylorista que separa radicalmente no trabalho, concepção de execução, são os fatôres que permitirão maior utilização da mão-de-obra.

No plano da dimensão da emprêsa desenvolvem-se as grandes corporations como na Grã-Bretanha e EUA, após a I Guerra Mundial; ampliam-se as sociedades por ações que produzem a quase totalidade dos bens públicos, como eletricidade, água e gás.

Passando a sociedade norte-americana da fase inicial de subconsumo e acumulação para a fase da abundância e alta produtividade, resolvidos os problemas econômicos mais imediatos, têm lugar, na emprêsa, os proplemas humanos que começam a ser atendidos. É quando se dá o surgimento da Escola das Relações Humanas com Elton Mayo; é quando no quadro da microemprêsa, a direção não

\footnotetext{
180 Fayol. op. cit. p. 134.

131 Weber, Max. Economia y sociedad. México, Ed. FEC, v. 4, cap. 5, p. 80 . "Não obstante, a disciplina do exército é o fundamento da disciplina em geral. O segundo grande instrumento disciplinador é a grande empresa economica". Weber, M. Economia y sociedad. v. 4, cap. 5, p. 80. 182 Taylor. op. cit. p. 75.

133 Fayol. op. cit. p. 39.

124 Já E. Mayo acentua a importância da comunicação na administração, mas coube a Chester Barnard elevar a categoria a uma noçăo de sistema. Na indústria cibernetizada constítui a realidade acabada do modélo "sistêmico".
} 
é função unificada de organição e coordenação, mas sim, ponto de união em que se combinam as exigências políticas e funcionais da emprêsa.

0 esquema de Mayo deveu-se a fatôres empíricos. Convidado a estudar agudo turnover, no departamento de fiação de um fábrica de tecidos em Filadélfia, calculado em $250 \%$, solucionou Mayo os problemas, criando um sistema alternativo de descanso a cada grupo, determinando o método e alternativa dos períodos, de modo que cada um dêles tivesse quatro períodos de repouso por dia. O sucesso deveu-se ao fato de as pausas terem permitido transformar, num grupo social um grupo solitário de trabalho.

A atitude do empregado, em face de seu trabalho, e a natureza do grupo do qual êle participa são fatôres decisivos da produtividade para Mayo. ${ }^{135}$

Elton Mayo aparece como um profeta secular, que critica a validade dos métodos democráticos para solucionarem os problemas da sociedade industrial, ${ }^{136}$ na medida em que a sociedade industrial burocratizada procura criar a cooperação forçada pela intervenção estatal. ${ }^{137}$

Na linha da Escola Clássica da Administração (Taylor, Fayol), Mayo não vê possibilidades de utilização construtiva do conflito social, que aparece para êle como a destruição da própria sociedade. ${ }^{138}$

Mayo vê na competição um sistema de desintegração social, na medida em que não leva à cooperação, acentuando êsse processo pelo conflito dos partidos políticos. ${ }^{139}$ Ele nos coloca diante de um ideal medieval de corporativismo: o cumprimento dêsse ideário corporativo cabe à elite dos administradores da indústria. ${ }^{140}$
Mayo partiu da análise de pequenos grupos segmentados do conjunto fabril, êste isolado da sociedade industrial, valorizando o papel do consenso do pequeno grupo para produzir mais, minimizando o papel da autoridade na indústria, o que leva - administrador da Escola de Relações Humanas a um "humanismo verbal" e à necessidade, às vêzes, de recorrer à autoridade formal para satisfazer as quotas de produção exigidas.

Para Elton Mayo a cooperação dos operários reside na aceitação das diretrizes da administração, representando um escamoteamento das situações de conflito industrial. Nesse sentido, êle continua a linha clássica taylorista, 141 êste acentuava o papel da contenção direta, aquêle a substitui pela manipulação.

Há uma incompatibilidade lógica no esquema de Mayo, qual seja, a luta pela cooperação espontânea e a luta por sua organização, incompatível com a existência de associações voluntárias.

Na sua crítica à Escola de Relações Humanas, a Escola Estruturalista já mostrara que o conflito industrial não é um mal em si, cabe manejá-lo construtivamente.

No plano institucional, Mayo atribui ao administrador um papel que êle dificilmente poderá cumprir, pois confunde conhecimento especializado (administrativo) com poder; daí propor a noção de uma elite administradora dominante. ${ }^{142}$

Apesar dos esforços de Mayo para tornar agradável o trabalho, as máquinas não evitam que 0 mesmo se torne satisfatório em nível absoluto. Embora Mayo veja o conflito como algo indesejável, o mesmo tem função, às vêzes, de conduzir a uma verificação de poder e do ajustamento da organização à situação real e, portanto, à paz. Acentuando o pêso do informal no trabalho, desmentido pelo fato de a maioria de operários não pertencer a grupos informais, Mayo cria condições para - aparecimento de uma crítica ao seu sistema: a abordagem estruturalista das organizações inicia-se assistemàticamente com algumas perspectivas lançadas por Marx, analisando a emprêsa oriunda da primeira revolução industrial e continuadas sistemàticamente por Max Weber na análise da emprêsa, produto da segunda Revolução Industrial.

A crítica estruturalista emergiu na Alemanha, embora não fôsse o país-modêlo da emprêsa burocrática, sob pressăo do alto nível político em que os assuntos sociais eram definidos, permitindo tornar a sociologia

135 Mayo, E. In: Sociologia de la industria y de la empresa. México, Ed. Uthea, 1965. "Sem dúvida muitos dos resultados năo eram 'novos'. Ch. Cooley nos EUA e W. Hellpech na Alemanha assinalaram com muita antecedência a importância

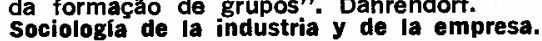
p. 50 .

130 "Os métodos da democracia, longe de proporcionarem os meios de solução do problema da sociedade industrial, provaram ser inteiramente inadequados para a tarefa." Mayo, E. Democracy and freedom,
an essay in social logic. Australia, 1919.

137 Mayo, E. op. cit. p. 48. "O Estado năo pode produzir a cooperação por meio da regulamentaçăo; a cooperaçăo apenas pode ser o resultado do crescimento espontâneo."

138 "O conflito é uma chaga social, a cooperação é o bem-estar social." Mayo, E. op. cit. p. 48.

130 "Em tôda a literatura dos séculos XIX e XX, apenas os defensores do Estado no trabalho pode ser reconquistada apenas pela integração do operariado, na da Administração." Bendix, R. \& Fisher, L. da Administração." Bendix, R. \& Fish As perspectivas de Elton Mayo. In: p. 126.

140 "Se tivéssemos uma elite capaz de realizar tal análise dos elementos lógicos e irracionais na sociedade, muitas das nossas dificuldades seriam praticamente
reduzidas a nada." Mayo, E. op. cit. p. 18.

141 "Ela (a abordagem das relações humanas) representa um adôrno da cooperação antagónica entre operários e administradores". Bendix, R. In: Etzioni, A. Organizacóes complexas. Ed. Atlas, 1962. p. 129.

16. A idéia de que a revolução do século $X X$ será "não dos operários, mas sim dos funcionários" explicitada por Weber, 1946. p. 67, enunciada por Elton Mayo neste contexto, foi explorada sistematica. mente por James Burnham em sua obra clássica The managerial revolution. New York, John Day Company, 1941. 
alemã uma resposta intelectual à Revolução Industrial, ao nível do Ocidente.

O esquema global de Elton Mayo fundamenta-se numa aproximação existencial (Hawthorne), a procura de uma compreensão dinâmica e global, valorização do informal, portanto da comunicação afetiva e simbólica levando a noção das dinâmicas de grupos, acentuando o papel da negociação e do compromisso, elaborando uma visão otimista do homem, uma pedagogia em nivel grupal e uma ação que visa mais à "formação" do que à "seleção". Negativamente, a Escola das Relações Humanas aparece como uma ideologia manipulatória que acentua a preferência do operário pelos grupos informais fora do trabaIho, quando na realidade, o operário sonha com a maior satisfação: largar o trabalho e ir para casa. ${ }^{143}$ Valoriza êste sistema símbolos baratos de prestígio, quando o trabalhador prefere a êstes, melhor salário. Essa escola procura acentuar a participação do operário no processo decisório, quando a decisão já é tomada de cima, a qual êle apenas reforça.

\section{CONCLUSAO}

No presente artigo abordamos o conceito de burocracia, desenvolvimento no plano lógico por Hegel, ${ }^{144}$ no histórico, pelas formações estatais definidas como o "modo asiático de produção". Nessas formações a burocracia detém o poder do Estado e constitui a própria classe dominante, cuja recorrência histórica situa-se nas formações dos Estados: chinês, russo, egípcio, babilônico, e na forma atual, a URSS e os paises que constituem o Bloco Oriental, China atual e Cuba. ${ }^{145}$

0 artigo enunciou as determinações histórico-sociais que presidiam a Revolução Industrial na França, Inglaterra e Alemanha fonte geradora das teorias explicativas de caráter "total" e global: Saint-Simon, Fourier e Marx.
A passagem da máquina a vapor à eletricidade, ocasiona a segunda Revolução Industrial e o surgimento das teorias de Taylor e Fayol. Enquanto as teorias sociais totais abordavam os processos macroindustriais, Taylor e Fayol têm, como ponto de partida, os aspectos microindustriais, um método de trabalho adequado a uma civilização em fase acumulativa de escassez e procura de rendimento máximo.

O taylorismo não se constitui sòmente num estudo técnico de tempos e movimentos, mas é influenciado pelo ethos puritano de origem quaker. Taylor desenvolve tôda uma paideia, ou seja, um ideal formativo de personalidade humana, em suma, uma visão do mundo.

Abordamos também a transposição das formas de disciplinas surgidas inicialmente na área militar para a área fabril, integradas na Escola Clássica da Administração. ${ }^{146}$

Por outro lado, a formação de holdings, a passagem da escassez à abundância, levará à enfatização do "fator humano" no trabalho com os estudos de Elton Mayo e a Escola das

Relações Humanas.

A partir dos enunciados assistemáticos de Marx no século passado, posteriormente à sistematização de Max Weber, aparece uma atitude crítica ante a Escola das Relações Humanas, vista como ideologia de manipulação da administração.

A ênfase de Elton Mayo na espontaneidade, no grupalismo, levarão posteriormente à formação das teorias administrativas fundadas nas técnicas de dinâmica de grupo. Essas técnicas acentuando a importância da comunicação na emprêsa, onde ela aparece como um "sistema" interligado e o operário um descodificador de sinais, cria as condições para a atual "teoria dos sistemas". Ela apresenta um máximo de formalização, em detrimento dos elementos históricos contingentes do processo industrial.

Em suma, as categorias básicas da teoria geral da administração são históricas, isto é, respondem a necessidades específicas do sistema social.

A teoria geral da administração é ideológica, na medida em que traz em si a ambigüidade básica do processo ideológico, que consiste no seguinte: vincula-se ela às determinações sociais reais, enquanto técnica (de trabalho industrial, administrativo, comercial) por mediação do trabalho; e afasta-se dessas determinações sociais reais, compondo-se num universo sistemático, organizado, refletindo deformadamente o real, enquanto ideologia.

Assim como as teorias macroindustriais do século passado de Saint-Simon, Fourier e Marx representaram a resposta intelectual ante os problemas oriundos da revolução industrial, as teorias microindustriais de Taylor-Fayol responderão aos problemas da era da eletricidade e a Escola das Relações Humanas, Estruturalista e Sistêmica refletirão os dilemas atuais.

148 Chinoy, E. Automobile workers and the American dreams. New York, Ed. Dubleday, 1955.

14 "A filosofia do direito, a peça mais grandiosa do pensamento hegeliano, contém um sabor tão profundo das realidades do mundo social e moral que nela reside uma sociologia concreta. A reflexao sobre - sistema da sociologia é reconduzida a sua fonte, guando se liga a filosofia do sociología, ciencia de la realidad. Buenos Aires, Ed. Losada, 1944. p. 244.

145 "A burocracia estatal reinaria absoluta se o capitalismo privado fôsse eliminado. As burocracias, pública e privada, que agora funciona lado a lado, e potencialmente uma contra outra, restringindo-se se-iam numa única hierarquia. Este Se-iam numa única hierarquia. Este no Antigo Egito, mas ocorreria de uma forma muito mais racional e por isso indestrutivel." Weber, Max. Parliament and government in Germany. Economy and society. New York,
1968. v. 3, p. 1402 .

146 Tal transposição já fôra notada no século passado por $K$. Marx quando enunciava que "a guerra se desenvolve antes que a paz: é necessário demonstrar como, pela guerra e nos exércitos, certas relaçóes económicas como o trabalho assalariado e o maquinismo surgiram nessa area, disseminando-se posteriormente Fe'o interior da sociedade burguesa." Marx, K. Contribution a la critique de I'economie politique. Paris, Editions Sociales, 1957. p. 172-73. 
As teorias administrativas são dinâmicas, elas mudam com a transição das formações socioeconômicas, representando os interêsses de determinados setores da sociedade que possuem o poder econômico-político, sob o capitalismo ocidental e o poder político-econômico nas sociedades que descrevemos, como formas recorrentes do modo asiático de produção.

No sentido operativo, elas cumprem a função de elemento mediador entre a macrossocie- dade e a microorganização pelo agente, 0 administrador. No sentido genético, constituem-se em repositório organizado de experiências, cuja herança cumulativa é uma condicionante das novas teorias, por exemplo, a persistência de aspecto tayloristas em Elton Mayo e na Escola Estruturalista.

Pode acontecer uma "reinterpretação cultural" - área de estudo da antropologia aplicada à administração - de modelos administrativos. Assim a assimilação que a URSS efetuou do taylorismo de 1918 até hoje, definindo-o com uma função diversa da que possui na sociedade norte-americana originária, atuando na URSS como uma técnica stakhanovista de intensificação do trabalho, num "sistema asiático de produção", que existe recorrentemente.

No próximo artigo concluiremos o tema, com a abordagem crítica dos modelos de Drucker, Katz \& Kahn, Max Weber e James Burnham, ainda no âmbito da teoria geral da administração como ideologia.

\section{SÉRIE BIBLIOTECA DE ADMINISTRAÇAO PóbLICA (BAP)}

Iniciada em 1953 com a edição de "ORGANIZAÇÃO E METODOS", de Harry Miller, a série vem obtendo êxito na tentativa de enriquecer a bibliografia especializada através da publicação de obras que reflitam a realidade administrativa.

Do esfôrço resultou a elaboração de manuais de indiscutlvel valia para os que se dedicam ao estudo e às atividades da administração pública, estudantes, administradores, economistas e cientistas sociais em geral, aos quais são oferecidos formulações de problemas administrativos.

A série "BIBLIOTECA DE ADMINISTRAÇAO PÚBLICA" inscreve-se, ainda, dentro do propósito de contribuir para a formulação de uma doutrina brasileira da administração pública.

Organização e Métodos

Harry Miller

BAP $14 .^{\mathrm{a}}$ edição (a sair)

Técnica de Administração Municipal Associacāo Internacional de Administradores Municipais

BAP 2

A Arte da Administração

Ordway Tead

BAP $32 .^{\text {a }}$ edição

Introdução à Administração Pública

Pedro Muñoz Amato

BAP 14." edição (a sair)

Introduçāo ao Planejamento Democrático John R. P. Friedman

BAP 5

Principios de Finanças Públicas

Hugh Dalton

BAP $62:^{a}$ edição

Problemas de Pessoal da Emprêsa Moderna Tomás de Vilanova M. Lopes

BAP $74 .^{\text {a }}$ edição

Administração de Pessoal - Princípios e Técnicas Beatriz M. de Souza Wahrlich BAP 8 2. a edição (a sair)

\author{
Direito do Trabalho \\ Délio Maranhão \\ BAP $92 .^{a}$ edição
}

O Ensino da Administração Pública no Brasil Marina Brandão Machado BAP 10

Classificação das Contas Públicas José T. Machado Jr.

BAP 11

Administração e Estratégia do Desenvolvimento A. Guerreiro Ramos BAP 12

A Intervenção do Estado no Domínio Econômico Alberto Venâncio Filho BAP 13

Comunicacão em Prosa Moderna Othon M. Garcia BAP $142 .^{a}$ edição

Fundações - No Direito, na Administração Clóvis Zobaran Monteiro e Homero Senna BAP 15

Planejamento Governamental Jorge Gustavo da Costa BAP 16

Custos - Um Enfoque Administrativo G. S. Guerra Leone BAP 17

Escola Brasileira de Administração Pública - Praia de Botafogo 190

Nas principais livrarias ou pelo reembôlso postal. Pedidos para a Editôra da Fundação Getúlio Vargas, Praia de Botafogo 188, CP 21.120, ZC-05, Rio de Janeiro, GB. 